\title{
Conserving reptiles within a multiple-use landscape: determining habitat affiliations of reptile communities in the northern Jarrah forest of south-western Australia
}

\begin{tabular}{|r|l|}
\hline Journal: & Australian Journal of Zoology \\
\hline Manuscript ID & ZO16074.R1 \\
\hline Manuscript Type: & Research paper \\
\hline Complete List of Authors: & $\begin{array}{l}\text { Triska, Maggie; The University of Western Australia, School of Biological } \\
\text { Sciences } \\
\text { Craig, Michael; University of Western Australia, School of Biological } \\
\text { Sciences; Murdoch University, Veterinary and Life Sciences } \\
\text { Stokes, Vicki; Alcoa of Australia, Environmental Research Department } \\
\text { Pech, Roger; Landcare Research } \\
\text { Hobbs, Richard; The University of Western Australia, School of Biological } \\
\text { Sciences }\end{array}$ \\
\hline Keyword: & \begin{tabular}{l} 
biodiversity, ecology, wildlife management \\
\hline
\end{tabular} \\
\hline
\end{tabular}


Conserving reptiles within a multiple-use landscape: determining habitat affiliations of reptile

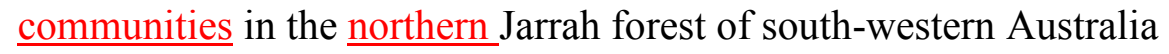

Maggie D. Triska ${ }^{\text {A,F }}$, Michael D. Craig ${ }^{\text {B,C }}$, Vicki L. Stokes ${ }^{\text {D }}$, Roger P. Pech ${ }^{\mathrm{E}}$, and Richard J. $\operatorname{Hobbs}^{\mathrm{A}}$

${ }^{A}$ The School of Biological Sciences, The University of Western Australia, Crawley, Western Australia 6009, Australia

${ }^{B}$ Centre of Excellence for Environmental Decisions, School of Plant Biology, The

University of Western Australia, Crawley, Western Australia 6009, Australia

${ }^{\mathrm{C}}$ School of Veterinary and Life Sciences, Murdoch University, Murdoch, Western Australia

6150, Australia

D Alcoa of Australia, Dwellingup 6213, Western Australia, Australia

${ }^{\mathrm{E}}$ Landcare Research, Lincoln 7640, New Zealand

${ }^{\mathrm{F}}$ Corresponding author. Email: mdtriska@gmail.com

RH: Reptile habitat affiliations in the Jarrah forest 


\section{Short Summary}

Identifying species' habitat affiliations is important for their conservation so we completed reptile surveys in the Jarrah forest, aiming to identify habitat affiliations for all reptile species detected, including rare species. Exploratory analyses provided guidance for further research and informed habitat management for all species, including rare species, but maintaining habitat heterogeneity and complexity will likely conserve the greatest number of species.

Abstract: Disturbed landscapes can provide habitat for a variety of species; however, for fauna, a strong understanding of their habitat affiliations is critical both to detect species and develop management prescriptions to maintain their populations. We assessed habitat affiliations of common, uncommon and rare reptile species in a multiple-use landscape, the northern Jarrah forest of south-western Australia. To identify predictors of reptile occurrence, we related reptile presence/absence, ${ }_{2}$ or relative abundance $_{2}$ to habitat, climatic and seasonal variables. Because the reptiles studied have cryptic behaviours and low numbers of detections, we used a combination of analyses including non-metric Multi-Dimensional scaling, occupancy and regression models. We identified specific habitat affiliations for the most common species and potential linkages with vegetation structure for most uncommon species. There were insufficient detections to determine habitat affiliations accurately for most rare species. Often species were detected too infrequently to determine specific habitat variables that influence occupancy and detection, and altering survey time and scale may increase detections so that habitat affiliations can be determined. However, in highly speciose $\underline{\text { landscapes, }}$ like our study area, we may not be able to wait until we have enough detections $\underline{\text { to define the habitat affiliations of all reptiles before we make management decisions. }}$ Therefore management activities that maintain habitat heterogeneity and complexity is likely to be the best strategy to conserve the most reptile species. 


\section{Introduction}

Biodiversity loss is increasing as humans clear and modify more of the earth's surface (Pimm and Raven 2000; Sala et al. 2000). Thus, if society is to conserve biodiversity in the face of increasing habitat clearance and modification, it is increasingly important to understand species habitat affiliations (Koellner and Schmitz 2006; Lindenmayer et al. 2012).

Understanding species' habitat affiliations enables the identification of important habitat features to maintain species' persistence. This is especially important in multiple-use landscapes, where identifying and predicting fauna species' habitat affiliations is critical for integrating conservation with competing extractive land uses (Morrison 2009), and in highly biodiverse communities, which occur primarily in tropical and southern temperate areas (Myers et al. 2000; Böhm et al. 2013) and contain many uncommon and rare species (Fisher et al. 1943; Magurran and Henderson 2003).

However, habitat affiliations are difficult to predict a priori in areas where the ecology of species is poorly known. Consequently, habitat affiliations of these elusive or rare species may, by necessity, be based on patterns of association from relatively few observations, increasing the probability of identifying spurious or incorrect habitat affiliations. Yet, because uncommon and rare species often form most of the biodiversity in hotspots, identifying their habitat affiliations significantly improves the ability to conserve biodiversity effectively. Furthermore, these uncommon and rare species may play an important role in maintaining ecosystem function during or after disturbances (Main 1982). Empirical (Hobbs et al. 2007) and theoretical studies (Yachi and Loreau 1999) support the importance of uncommon and rare species in the environment and suggest that they may become more critical as environments experience climate change. 
The standard analysis for identifying habitat affiliations in community-wide studies is to model detectability with habitat variables, but this method can be data hungry and, hence is suitable only for the most common species unless the sampling effort is increased to adequately detect rare species (Fischer et al. 2004; Garden et al. 2007). Additionally, modelling detectability on sparse data from uncommon or rare species can often be worse than not accounting for detectability at all (Welsh et al. 2013). Therefore, different approaches need to be considered for identifying habitat affiliations of uncommon and rare species, and our goal here is to balance accurate data interpretation with useful analysis methods. Species specific habitat and behavioural information is often lacking for many Australian vertebrates and this is particularly true for reptiles (MacNally and Brown 2001). Part of the reason for this is that Australia has the world's most speciose reptile fauna (Groombridge 1992) and Australian reptile communities typically contains a high proportion of rare and uncommon species (Pianka 1986, 1989). Furthermore, reptiles may have specific habitat requirements that are not shared with other vertebrate groups because, unlike the best studied faunal groups, birds and mammals, habitat suitability for poikilothermic reptiles is heavily dependent on specific thermal conditions. This makes abiotic determinates such as climatic (thermal), seasonal variables and habitat structure critical in determining reptile habitat affiliations by influencing activity times, survival, reproduction, foraging and protection from predators (Heatwole and Taylor 1987; Adolph and Porter 1993; SpenceBailey et al. 2010). This combination of high species richness, low abundance of many species and diverse habitat requirements means that elucidating the habitat affiliations and requirements of many reptile species will be critical for conserving biodiversity in Australia. 
The northern Jarrah (Eucalyptus marginata) forest, a multiple-use forest in south-western Australia, lies within a biodiversity hotspot (Myers et al. 2000). The rich and unique biodiversity in the region is potentially threatened by habitat loss and alteration from multiple competing land uses (mining, logging, agriculture, fire management, water catchments and recreational use (Dell and Havel 1989; Gardner and Bell 2007)). Hence, it is essential to understand the habitat affiliations of the most species in the Jarrah forest to identify important habitats or features to help conserve its biodiversity (Yeatman et al. 2017). Specifically, the Jarrah forest has high reptile species richness ( 45 species [Nichols and Muir 1989]), with the majority of species being small $(<8 \mathrm{~g})$ and rare, with patchy distributions or cryptic behaviours (Craig et al. 2009). These characteristics make Jarrah forest reptile species difficult to detect, and hence study and monitor (Williams and Mitchell 2001; Nichols and Grant 2007; Craig et al. 2009) and currently we know very little about many of the species' habitat affiliations. In this study we aimed to determine the habitat affiliations of as many reptiles as possible in the northern Jarrah forest based on vegetation structure, climatic or seasonal variables and, if required, assess common, uncommon and rare reptile species using different analyses to best predict their habitat affiliations.

\section{Materials and Methods}

Study Area

This study was conducted within Alcoa of Australia's (hereafter, Alcoa) Huntly mine lease $\sim 10 \mathrm{~km} \mathrm{~N}$ of Dwellingup in the northern Jarrah forest $\left(32^{\circ} 36^{\prime} \mathrm{S}, 116^{\circ} 06^{\prime} \mathrm{E}\right)$. The Jarrah forest is a dry, open sclerophyll forest endemic to south-western Australia, where the canopy is dominated almost entirely by the two eucalypts Jarrah and Marri (Corymbia calophylla). Common midstorey species include Sheoak (Allocasuarina fraseriana), Bull Banksia (Banksia grandis) and Snottygobble (Persoonia longifolia) (Dell and Havel 1989). The area 
has a Mediterranean climate (Dell and Havel 1989) with temperatures ranging from mean maxima and minima of $15.0{ }^{\circ} \mathrm{C}$ and $5.4{ }^{\circ} \mathrm{C}$ in July to $29.6{ }^{\circ} \mathrm{C}$ and $14.5^{\circ} \mathrm{C}$ in February. Average annual rainfall is $\sim 1236 \mathrm{~mm}$ at Dwellingup, the nearest weather station, with average rainfall peaking in July (208.7 mm; Bureau of Meteorology, http://www.bom.gov.au/climate/data/).

\section{Study Design}

We obtained data from 35 trapping arrays distributed randomly throughout reference areas at the Huntly mine lease (Fig. 1) which covers $\sim 160 \mathrm{~km}^{2}$. We defined reference areas as areas without current or previous mining which represent Alcoa's aim for current restoration practices. It is important to determine reptile habitat affiliations in these reference areas to later define an expectation and comparison for reptile occupancy in the successional stages of restoration. To best represent reference areas, survey sites were selected to minimize anthropogenic influences and therefore, we avoided forest infested with Phytophthora cinnamomi (an invasive plant pathogen), and areas burnt $<5$ years previously. To obtain a broad spatial spread across the mine lease while minimising potential edge effects (but see Craig et al. 2015) from cleared, mined and restored forest ${ }_{2}$ all sites were located $>70 \mathrm{~m}$ from current or past mining and post-mining restoration. To detect the greatest variety of species, and capture as much of the reptile community as possible, including uncommon and rare species, we employed pitfall, funnel, Elliott and cage traps. All surveys used the same trapping arrays (Fig. S1 consisting of a $29 \mathrm{~m}$ aluminium fly-wire drift fence $(\sim 30 \mathrm{~cm}$ tall) with 9 pitfall traps (three $\underline{41 \mathrm{~cm} \text { high by } 28 \mathrm{~cm} \text { diameter } 20 \mathrm{~L} \text { plastic buckets, four } 11.3 \mathrm{~cm}}$

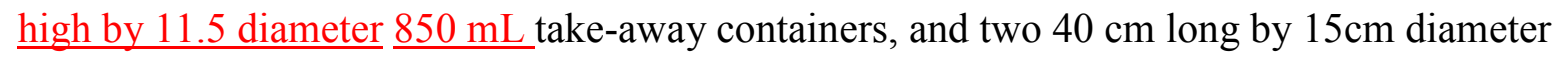
PVC tubes) located every $3 \mathrm{~m}$ along the fence, 4 funnel traps (two paired on each side of the drift fence) located $7 \mathrm{~m}$ from either end of the drift fence between the take-away containers 
and the PVC tubing, 4 Elliott traps located $5 \mathrm{~m}$ on either side of the end 20 L buckets, and 1 cage trap located $5 \mathrm{~m}$ from one of the end $20 \mathrm{~L}$ buckets. Elliott traps were baited with universal bait (peanut butter and rolled oats) and honey and contained shredded paper for warmth while pitfall traps were unbaited. Elliot traps were baited as data was also collected on mammals, but these mammal data are not presented here. Sites were surveyed between 2005 and 2012, although not every year, during the seasons when reptiles were active: 5 days/4 nights during October (early spring), December (early summer) and March (early autumn), with some sites additionally surveyed in November (late spring) (see Table S1). All individuals captured during surveys were identified to species and skinks (except Egernia napolenois and Tiliqua rugosa because of their large size and Lerista microtis as only one was detected) were individually marked by removing 1 or 2 toes $(94.4 \%$ and $5.6 \%$ of the individuals marked, respectively), unless they had natural toe loss $(\sim 5.2 \%)$, and released at their capture site.

We completed structural assessments at each of the arrays after the completion of trapping to quantify habitat variables. There was some variation in the precise methodology between years (i.e. size of the survey area or number of estimates), but the majority of surveys were completed using the following method. Visual estimates of percent litter cover and bare ground and all vegetation in three strata $(0-1 \mathrm{~m}, 1-2 \mathrm{~m}$ and 2-5 m) were made within twelve $0.25 \mathrm{~m}^{2}$ plots at 5 and $10 \mathrm{~m}$ on either side of all $20 \mathrm{~L}$ bucket pitfalls. Understorey $(<3 \mathrm{~m}$ in height) and overstorey ( $>3 \mathrm{~m}$ in height) plant densities were determined by measuring the distance from the centre of $0.25 \mathrm{~m}^{2}$ plots to the closest understorey or overstorey plant and averaging distances to get density estimates using the formula from Barbour et al. (1987). Canopy cover was recorded by taking vertical digital images above the centre of $0.25 \mathrm{~m}^{2}$ plots and classifying crown cover from the images (Pekin and Macfarlane 2009). Earlier http://www.publish.csiro.au/journals/ajz 
surveys (pre-2011) used a densiometer to measure canopy cover and estimates from those years were calibrated with canopy photograph estimates before analysis. Canopy height was estimated from the height of the 5 tallest trees within $40 \mathrm{~m}$ of the trapping grid, measured using a tree vertex, and coarse woody debris $(\underline{\mathrm{CWD}}>>5 \mathrm{~cm}$ in diameter at one end) was estimated by measuring the diameter and length of all debris within $5 \mathrm{~m}$ of the drift-fence. In addition we included the fuel age (determined from GIS data at the Western Australia Department of Parks and Wildlife) and the proportion of restored area within $100 \mathrm{~m}$ of the array to assess additional anthropogenic landscape influences (see below). The climatic variables calculated were the maximum and minimum temperature for each trapping day (averaging the day before and the day of checking) and the precipitation within two weeks preceding the day of the trapping session (http://www.bom.gov.au/climate/data/; summary of all habitat variables in Table S2). Information on the month and year of surveys (seasonal variables) were recorded to determine the influence of these categorical variables on reptile detectability and occupancy.

$\underline{\text { Overall, our study was designed to gain information on reference areas and avoid the impacts }}$ $\underline{\text { of anthropogenic disturbances; however, we acknowledge that reptile relationships with }}$ disturbances are well documented and the impacts of fire (Schmidt and Mason 1973, Penn et al. 2003, Kavanagh and Stanton 2005, Driscoll and Henderson 2008), logging (Goldingay et al. 1996, Kavanagh and Stanton 2005) and mining (Taylor and Foxx 2001) likely exist in our

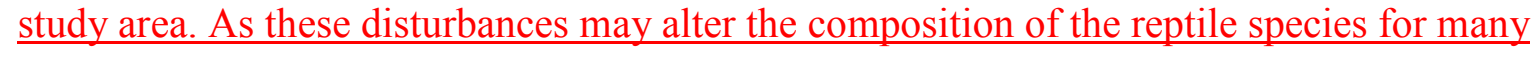
years (Taylor and Fox 2001), we assessed time since fire and the proportion of mined and $\underline{\text { restored area; however, the influence of logging was not addressed as it is rarely possible to }}$ quantify the intensity of logging and, even with years of trapping data, it is challenging, if not 


\section{impossible, to assess the influence of logging on small vertebrate species of the Jarrah forest}

\section{(Wayne et al. 2001).}

\section{Statistical Analyses}

Trapping data were converted into presence/absence detection histories $(0=$ absent, $1=$ present) for each species by site (with recapture events being removed prior to analysis, $\sim 3.7 \%$ of individuals were recaptured $)$ or, for less common species ( $<10 \%$ of detections), left as the count of individuals captured. These abundance classifications were based on the ability to analyse the data; rare species $(<1.5 \%$ of detections) relationships were potentially spurious and no individual analyses could be completed on them, uncommon species (between 1.5 and $10 \%$ of detections) did not contain adequate detections for occupancy modelling, but did for Poisson regressions, and common species ( $>10 \%$ of detections) were regularly detected and did not have any analysis restrictions. To assess the sampling regime and survey effort, we completed species accumulation curves on the number of detections per day for each species after correcting for the number of sites surveyed each day.

We removed habitat and climatic variables that were highly correlated $\left(r_{33}>0.60\right)$, which resulted in the removal of bare ground (correlated with litter cover $r_{33}=0.65$ ) and understorey density (correlated with cover from 1 to $2 \mathrm{~m}, r_{33}=0.73$ ) from analyses. To define community groupings, we performed non-metric multidimensional scaling (nMDS) on the relative abundance (i.e. individual counts) of each species at each site (common, uncommon and rare) detected, with singletons removed to avoid errors in the analysis (L. microtis only). The rank order correlation of the data by site was explored, along with the fitted habitat variables relationship with the nMDS ordination, using the function Bioenv which compares the dissimilarity matrices of the species and habitat variables to determine a best subset of habitat http://www.publish.csiro.au/journals/ajz 
variables (Clarke and Ainsworth 1993). This subset of habitat variables was then assessed through permutation tests to determine the significance using Procrustes analyses.

Single species multi-season occupancy models (also referred to as dynamic occupancy models (MacKenzie et al. 2003; Kéry et al. 2013)) were only ran for the 5 common species (Acritoscincus trilineatus, Hemiergis initialis, Lerista distinguenda, Menetia greyii, and Morethia obscura) as these analyses were unable to be conducted on species with fewer detections. Occupancy was predicted using maximum likelihood estimation (MacKenzie 2006) and we assessed the impact of habitat, climatic and seasonal variables on probability of detection (p) and occupancy $(\psi)$. First, the best models for detection probability were determined based on climatic and seasonal variables (e.g. p(MaxT) $\psi()=$. detection probability is influenced by maximum temperature and occupancy is constant). Next combined models ( $\mathrm{p}$ and $\psi$ ), which used the best models for detection probability, were added to occupancy with different habitat variables (e.g. p(MaxT) $\psi(0-1 \mathrm{~m})$; where detection probability is influenced by maximum temperature and occupancy by the percent cover from 0 to $1 \mathrm{~m}$ ). The Akaike information criterion (AIC; Burnham and Anderson 2002) was used to determine top models with associated variables. All well-supported models, which we define as those with $\triangle \mathrm{AIC} \leq 2$ from the top model, were retained (Burnham and Anderson 2002) and if models that had $\omega<0.9$, multiple models were considered plausible (Burnham and Anderson 2002). Parametric bootstrapping $(n=1000)$ of the models determined the fit of the models (Kéry et al., 2005; Kéry et al. 2013) by generating a fit statistic (SSE, or Chi-square) for the top AIC model of each species, with large $P$-values indicating no evidence of lack of fit of the top model. 
We determined potential habitat affiliations of uncommon species (Christinus marmoratus, Cryptoblepharus buchananii, Ctenotus labillardieri, Diplodactylus lateroides and E. napoleonis), using Poisson regression models in which the outcome (relative abundance) was modelled as a linear combination of the predictor variables (habitat covariates). Model averaging was completed to define significance of the habitat covariates quantified by summing the weights of a subset of models with $\triangle \mathrm{AICc}<2$, and consideration was taken (i.e. variables removed, under/over dispersion evaluated) to reduce issues arising from collinearity in model averaging (Cade 2015). Additionally, we report the relative importance of variables, as outlined in Cade (2015), as the absolute value of the z-values weighted by the maximum value. This weights the most important variable as 1.00 and all other variables in relation to it, to incorporate effect size and variance instead of focusing on the number of times a variable is present in the model subset. Relative importance values $>0.5$ were considered to be important.

All analyses were completed in R 2.14.1 (R Core Development Team 2016). The nMDS was completed using function Bioenv in package "Vegan" (Oksanen et al. 2015), occupancy models were generated using package "unmarked" (Fiske and Chandler 2011) and Poisson regression (glm) models were available within the core application of $\mathrm{R}$, with model averaging completed with package "MuMIn” (Barton 2013).

\section{Results}

Across all surveys, we captured 706 individuals of 17 reptile species. The number of detections, excluding recaptures, for each species, over 8,840 trap nights, ranged from 171 for M. obscura to 1 for L. microtis (Table 1). The 5 most common skink species comprised $>80 \%$ of all individuals captured, uncommon species accounted for $\sim 17 \%$ of detections and http://www.publish.csiro.au/journals/ajz 
rare species the remaining 3\% (see Table 1 for a species list and categories and Fig. S2 for photos of the most common species detected). Additionally, species accumulation curves verified that the sampling regime and number of surveys were adequate to document the reptile biodiversity identified as occurring in the study area by Nichols and Nichols (2003), $\underline{\text { with any other reptiles potentially occurring either extremely rare or requiring specific }}$ sampling methods to detect (Fig. S3).

Three habitat variables, percent cover from 0 to $1 \mathrm{~m}$, overstorey density and leaf litter, were most correlated $(0.20)$ with overall reptile community composition. Based on visual assessments of the nMDS and habitat variables there appear to be three potential groupings of species based on abundances and habitat affiliations (Fig. 2). One potential group, comprising five skinks (M. greyii, M. obscura, L. distinguenda, C. buchananii, and T. rugosa), one gecko (D. lateroides) and one elapid (Parasuta nigriceps), occurred in sites with low understorey density and more open forest structure. Another potential group, consisting of two skinks ( $E$. napoleonis and A. trilineatus) and one dragon (Pogona- minor) was associated with increased ground (0-1 m) cover and overstorey density, representing sites with a denser forest structure. The last potential group was associated with increased leaf litter and included two skinks $(H$. initialis and C. labillardieri) one pygopodid (Aprasia pulchella) one blind snake (Ramphotyphlops australis) and one gecko (C. marmoratus). Varanus rosenbergi [Varanidae] did not separate obviously into any group and no habitat affiliations were identified for this species.

For occupancy models, in step one, species detection probabilities were influenced by climatic $(n=4)$ and seasonal $(n=1)$ variables (Table 2 and Fig. S4). Maximum temperature (mean \pm SE: $24.9 \pm 0.20$, range: $15.5-36.3{ }^{\circ} \mathrm{C}$ ) influenced detection probabilities for $M$. 
obscura, M. greyii, L. distinguenda and A. trilineatus. Two species displayed quadratic trends with temperature whereby their detection increased to an optimal temperature and then decreased (optimal temperatures, detection probability $\pm \mathrm{SE}$ : M. obscura $31.2^{\circ} \mathrm{C}, \mathrm{p}=0.49 \pm$ 0.05; L. distinguenda, $\left.33.0^{\circ} \mathrm{C}, \mathrm{p}=0.44 \pm 0.08\right)$. M. greyii and A. trilineatus detection probabilities both increased linearly as temperature increased. H. initialis detectability was influenced by month $($ March $p=0.04$, October $p=0.29$, November $p=0.16$, December, $p=$ $0.35)$

The well-supported models for $A$. trilineatus suggested that occupancy increased with vegetation cover from 2 to $5 \mathrm{~m}$. H. initialis had four well-supported models, and showed preferences for decreased CWD and increased cover from 0 to 1 and 1 to $2 \mathrm{~m}$ and overstorey density. In the well-supported models for L. distinguenda, occupancy increased with decreased cover from 0 to $1 \mathrm{~m}$ and overstorey density. M. greyii occupancy increased as cover from 1 to 2 and 2 to $5 \mathrm{~m}$ decreased. $M$. obscura occupancy increased as overstorey

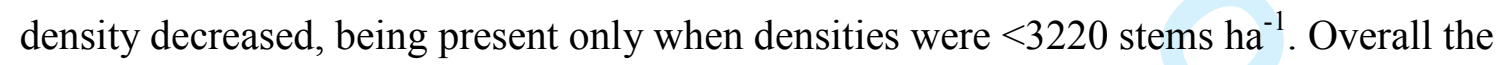
models suggest that $A$. trilineatus and $H$. initialis prefer dense understorey and overstorey and L. distinguenda, M. greyii, and M. obscura prefer open areas with low cover. None of the goodness of fitness tests were significant indicating that models represented the data well. Interestingly, the models also matched the outputs from the nMDS community grouping $\underline{\text { results as well. }}$

Poisson models showed potential links between uncommon species and multiple habitat covariates (Table 3). Significant relationships between species relative abundances and habitat covariates were identified for D. lateroides and C. marmoratus with relative importance indicating strong positive relationships between $D$. lateroides and CWD and a http://www.publish.csiro.au/journals/ajz 
strong negative relationship between C. marmoratus and cover from 0 to $1 \mathrm{~m}$ (Table 3 ).

Relative importance also indicated well-supported, positive relationships between $E$.

napoleonis and cover from 0 to $1 \underline{\text { and }} 2$ to $5 \mathrm{~m}$ and a negative relationship with fuel age

(Table 3). Ctenotus labillardieri also displayed a well-supported negative relationship with

$\underline{\text { fuel age (Table 3). Additionally, C. buchananii had well-supported positive relationship with }}$

fuel age and a negative relationship with cover from 0 to $1 \mathrm{~m}$ (Table 3). Again, the results from these preliminary analyses matched the outputs from the community groupings well.

\section{Discussion}

We generated species specific models for 10 of the 17 detected reptiles (only the 5 most common included probability of detection), showing it is possible to define habitat affiliations for common and uncommon species using standard plot-based survey methods. However, cryptic and rare species' habitat affiliations were more difficult to determine with these methods, as they needed to be based on community level analyses. Our results suggested the community level analyses may identify habitat relationships for some rare and cryptic species but that it would be unlikely to identify potential relationships for those rare and cryptic species that were detected using general trapping methods.

\section{Common reptiles}

The habitat affiliations identified from the majority of our models for common species agreed with habitat affiliations observed in the limited previous studies present on reptiles in the Jarrah forest. M. obscura, M. greyii and L. distinguenda occupied forest areas that had low overstorey density and/or cover and overall a more open forest (Smith et al., 1996; Nichols and Muir 1989; Bush et al. 2007; Craig et al. 2010; Craig et al. 2012). Increased leaf litter, which is important for L. distinguenda and M. greyii (Pianka 2011a) specifically, may 
provide preferred foraging habitat if associated with highest abundance of preferred invertebrate prey (Simmonds et al. 1994; Cuccovia and Kinnear 1999; Majer et al. 2007). Decreased overstorey density likely provides an increased abundance of basking sites for all three species (Blouin-Demers and Weatherhead 2001). Hemiergis- initialis was associated with multiple habitat covariates, which all suggest a link to increased habitat cover and complexity. Similarly, Craig et al. (2012) found that this species was related to increasing canopy height and CWD, which are likely proxies for sites that have greater productivity and habitat complexity. Acritoscincus- -trilineatus preferred dense habitats with increased low cover $(<5 \mathrm{~m})$, which was expected as they are often associated with stream zone vegetation with dense understorey (Nichols and Bamford 1985; Nichols and Muir 1989; Craig et al. 2012). Overall, the five most common species partitioned into two groups, with three preferring open forest and two associated with dense forest, suggesting that a heterogeneous landscape would help maintain populations of these species. Importantly, these preferences for open or dense forests were congruent between the community and individual species analyses and matched the few previous studies conducted on our common species.

\section{Uncommon reptiles}

Uncommon species' habitat affiliations, with the exception of E. napoleonis, were more difficult to substantiate due to a lack of species-specific studies. Egernia- napoleonis appeared to prefer sites with low cover, which matches other studies that found this species preferred more open sites (Craig et al. 2011). Egernia napolenis also displayed a link to $\underline{\text { decreased fuel age, which likely relates to cover as a study on E. napoleonis in restored sites }}$ suggested that they do not have a preference for burn age of logs (Christie et al. 2013). The presence and status of logs is important to E. napoleonis and they often display links with CWD when comparing restored and reference forest (Craig et al. 2012). This study focuses http://www.publish.csiro.au/journals/ajz 
only on reference forest, and it is likely that most reference forest areas at Huntly have sufficient CWD for E. napoleonis, as forests in our study area, have on average, $121 \operatorname{logs~ha}^{-1}$ (Whitford et al. 2008) and E. napoleonis typically requires 50 logs ha-1 (Christie et al. 2013). Additionally, D. lateroides preferred areas with more CWD and the species is known to shelter under logs (Bush et al. 1995). However, other studies have suggested a preference for open rocky areas (Nichols and Bamford 1985; Bush et al. 2007) or areas with low litter cover (Craig et al. 2012) suggesting this species' habitat preferences may be more complex than our study identified, although the preference for areas with greater CWD volumes may be real. We determined that $C$. labillardieri preferred areas with younger fuel ages which matches well with anecdotal observations that the species prefers areas of dense cover (Nichols and Bamford 1985). The species also inhabits wet sclerophyll Karri (E. diversicolor) forests (Bush et al. 1995), again suggesting a preference for areas with high cover. The strongest relationship for C. buchananii was a strong positive relationship with fuel age and, $\underline{\text { to a lesser extent cover from } 0 \text { to } 1 \mathrm{~m}}$. A study in the Banksia woodlands also found that they prefer long unburnt areas within the Banskia woodlands (Valentine et al. 2012); however other studies in the Jarrah forest found that this arboreal species favours tree trunks (Pianka and Harp 2011) and shelters in crevices in dead wood (Nichols and Bamford 1985) and hence may prefer low cover. The strongest relationship for $C$. marmoratus was a negative relationship with cover from 0 to $1 \mathrm{~m}$ and the few previous studies on this arboreal species have indicated it preferred areas with high densities of large trees and also sheltered under logs (Claridge et al. 2003; Cunningham et al. 2007). The Jarrah forest tends to have an open $\underline{\text { understorey when trees are over 30m (Ashton and Attiwill 1994); hence, it is likely that, in }}$

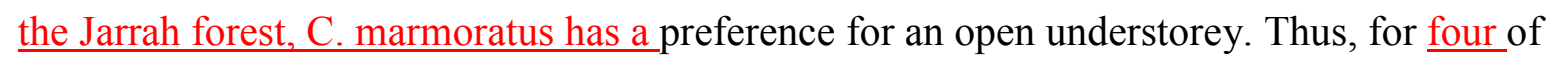
our uncommon species (D. lateroides, C. labillardieri, C. buchananni and C. marmoratus), our results matched well with previous studies, although, for one species_(E. napoleonis), our http://www.publish.csiro.au/journals/ajz 
study may not have identified all the habitat affiliations. Like our common species, though, there was good congruence between relationships identified from community and individual species analyses.

\section{Rare reptiles}

Our community analyses suggested that, although habitat affiliations could not be identified for $V$. rosenbergi, most rare and cryptic species seemed either to be associated with open or closed forests. The difficulty with these rare and cryptic species is that they are typically unknown ecologically and so it is not possible to determine whether these broad habitat affiliations are accurate. Our community analyses suggested that $P$. minor was associated with closed forests and this matches well with the few studies published on this species. Craig et al. (2007) reported that $P$. minor preferred sites with greater cover of dead plants between 0 and $1 \mathrm{~m}$ than random samples, while Craig et al. (2012) found that $P$. minor abundance increased with increasing understorey density. Results from these two studies are consistent with $P$. minor preferring closed forests and suggests that our community analyses accurately identified broad habitat preferences for this species. Two rare or cryptic species $(R$. australis and $A$. pulchella) were associated with dense leaf litter. Although the dearth of ecological information on these species make it impossible to evaluate the likelihood this association is true, anecdotal observations are that R. australis favours damp conditions (Bush et al. 1995) and shelters beneath leaf litter (Bush et al. 2007) while A. pulchella both forages (Bush et al. 1995) and shelters beneath leaf litter (Bush et al. 2007). These qualitative observations suggest that a preference for areas with high litter cover might be accurate reflection of true habitat affiliations. Our community analyses suggested that T. rugosa and $P$. nigriceps prefer open forests. Little is known about $P$. nigriceps to support the likelihood of this habitat 
a preference for areas that have low dense bushes (Fergusson and Algar 1986; Kerr et al. 2003; Kerr and Bull 2004) but these habitats were more open than the Jarrah forest although one study from the Jarrah suggested a preference for closed forest due to a positive relationship between T. rugosa and overstorey density (Craig et al. 2012). We believe these contrary results likely arise due to the mismatch between the spatial scale of the sampling arrays and the spatial scale of T. rugosa home ranges which results in detections leading to the identification of spurious relationships due to inaccurate measures of the distribution and abundance of T. rugosa. Tiliqua rugosa can have home ranges $>5$ ha (Bull and Freake 1999; Kerr and Bull 2006) and we believe that the inability of the community analyses to identify habitat affiliations for $V$. rosenbergi and unverifiable predictions for $P$. nigriceps also result from the same issue. Varanus - rosenbergi can have home ranges $>40$ ha (Green and King 1978 ) and it is likely that $P$. nigriceps, whose home range is unknown, is likely to have a home range size similar to another elapid Hoplocephalus stephensii, which can have home ranges $>20$ ha (Fitzgerald et al. 2002). It is well known that sampling plots most effectively detect the distribution and abundance of species if they are the around the same size, or larger, than the home ranges of individual species (Craig and Roberts 2005; Fischer et al. 2004; Morrison et al. 2006). Thus, the community analyses appeared to correctly identify habitat affiliations for one rare species $(P$. minor $)$ and likely correctly identified affiliations for two further species (R. australis and A. pulchella). However, community analyses did not accurately identify habitat affiliations for the remaining three rare species $(T$. rugosa, $P$. nigriceps and $V$. rosenbergi), probably because these species had large home ranges.

\section{Management outcomes}

The results of our study highlighted issues that are likely to be typical of studies investigating habitat affiliations of reptiles in Australia, which has the world's richest reptile fauna http://www.publish.csiro.au/journals/ajz 
(Groombridge 1992). Namely, that most species will be recorded very infrequently (Pianka 1989; Thompson et al. 2003; Pianka 2011b), due to either rarity or crypsis, and that habitat affiliations will be difficult to identify for these rarely caught species. The standard trapping arrays used were designed to maximise captures rates across all species and therefore have $\underline{\text { lower capture rates for large, rare and cryptic reptiles and we were unable to identify their }}$ $\underline{\text { habitat associations with any confidence. Additionally, even with our extensive trapping }}$ $\underline{\text { effort we failed to capture some species (e.g. carpet python) that occur in the study area. For }}$ these species target survey methods including the use of active searches, coverboards and motion-sensitive cameras (e.g. Ryan et al. 2002; Kanowski et al. 2006; Welbourne et al. 2015), might obtain sufficient detections that combined with innovative methods of analysing the data collected (e.g. Sutherland et al. 2016), might correctly identify their habitat affiliations. Alternatively, using adaptive sampling methods, which expand trapping and habitat surveys based the location of detections of focal species to adjacent areas around these detections (Thompson and Seber 1996; Morrison et al. 2008), or using niche-based models (Guisan et al. 2006) to better target areas for sampling, may also improve detection rates for rare species although the number of detections is still likely to remain too small to identify habitat associations for many rare species. Radio-tracking is often an effective method of identifying habitat affiliations and resource requirements for rare species and has been widely used (e.g. Green and King 1978; Fitzgerald et al. 2002) but it is labour intensive, meaning only a few rare species could be studied contemporaneously using this method. Radiotracking is appropriate for large species, but its use may be limited for rare species as they can only be placed on species with a body mass $>4 \mathrm{~g}$ and harmonic radar enables the tracking of species $>2 \mathrm{~g}$ in predominantly open areas only (Gourret et al. 2011). The issues identified with these methods, combined with the scarcity of long-term studies, the high richness of Australian reptile communities and the remoteness of much of the Australian landmass http://www.publish.csiro.au/journals/ajz 
means, however, that short-term plot based studies are likely to remain the primary method of identifying habitat affiliations for most rare species in Australia. This means that identifying $\underline{\text { habitat associations for many rare species in highly speciose communities will remain }}$ $\underline{\text { impossible, even with extensive surveys and suggests that we cannot wait until we have }}$ $\underline{\text { identified habitat affiliations for all reptiles in order to implement effective conservation }}$ plans. Our study suggests that implementing management activities that maintain habitat $\underline{\text { heterogeneity and complexity will be the most effective strategy for conserving the most }}$ reptile species. This was exemplified in our study by the fact that the important habitat variables for various species related to the ground, understorey, overstorey and no single habitat variable was identified as 'most important', even at the community level.

\section{Conclusion}

Our study suggests that, for species with small home ranges, community analyses of data from plot based studies likely identifies habitat affiliations for many common and uncommon species. However, given the uncertainty surrounding which affiliations were correctly identified, and the dearth of information to verify any postulated affiliations, it would be prudent to treat affiliations for rare species as hypotheses to be tested by further study (Doak et al. 2005). Our study also suggested that, while different reptile species can have similar habitat affiliations, there was a wide variety of affiliations among different species. Together these results suggest that, until habitat affiliations are identified for many uncommon and rare reptile species, it would be prudent to retain as much habitat heterogeneity and complexity as possible across landscapes. Habitat heterogeneity is typically associated with increased species richness (Schoener 1974) and is known to be important in maintaining speciose reptile communities (Brown and Nelson 1993; Nichols and Nichols 2003; Fischer et al. 2004;

Driscoll et al. 2012). Habitat heterogeneity in Australia will typically involve appropriate http://www.publish.csiro.au/journals/ajz 
prescriptions to manage disturbance, such as fire (Driscoll et al. 2012; Pianka and Goodyear 2012) and thinning (Kutt et al. 2012; Eyre et al. 2015), to maintain sufficient patches of different post-disturbance ages at an appropriate spatial scale. This is likely to prove increasingly challenging as more landscapes are affected by anthropogenic activities, but will be necessary to effectively conserve our rich herpetofauna with limited ecological knowledge.

\section{Acknowledgments}

We thank John Kanowski, Michael Morrison and Dan Lunney for their suggestions on this manuscript and the Wildlife Preservation Society of Australia (WPSA), School of Plant Biology, University of Western Australia, Alcoa of Australia, and ARC Linkage LP0882687 for funding. MDT was supported by a Scholarship for International Research Fees and Australian Postgraduate Award Industry. The study was completed under ethics approval UWA AEC RA/3/900/029 and Murdoch AEC W2274/09 and DPAW licenses Reg. 17 SF008315 and Reg. 4 CE003385.

\section{References}

Adolph, S. C., and Porter, W. P. (1993). Temperature, activity, and lizard life histories. The American Naturalist 142, 273-295.

Ashton, D. H., and Attiwill, M. P. (1994). Tall open-forests. In 'Australian Vegetation'. (Ed.

$\underline{\text { R. H. Groves.) pp.157-196. (Cambridge University Press: Cambridge.) }}$

Barbour, M. G., Pitts W. D., and Burk, J. H. (1987). 'Terrestrial Plant Ecology.'2 2nd edn. (Benjamin-Cummings Publishing Company: Menlo Park.) 
Barton, K. (2013). Multi-modal inference. R package version 2.0-5.

Blouin-Demers, G., and Weatherhead, P. J. (2001). Thermal ecology of black rat snakes (Elaphie obsoleta) in a thermally challenging environment. Ecology 82, 3025-3043.

Böhm, M., Collen, B., Baillie, J. E., Bowles, P., Chanson, J., Cox, N., Hammerson, G.,

Hoffmann, M., Livingstone, S. R., Ram, M., Rhodin, A. G. (2013). The conservation status of the world's reptiles. Biological Conservation 157, 372-385.

Brown, G. W., and Nelson, J. L. (1993). Influence of successional stage of eucalyptus regnans (mountain ash) on habitat use by reptiles in the central highlands, Victoria. Australian Journal of Ecology 18, 405-417.

Bull, C. M., and Freake, M. J. (1999). Home-range fidelity in the Australian sleepy lizard, Tiliqua rugosa. Australian Journal of Zoology 47, 125-132.

Burnham, K. P., and Anderson, D. R. (2002). 'Model Selection and Multimodal Inference: A Practical Information-theoretic Approach.' 2nd edn. (Springer: New York.)

Bush, B., Maryan, B., Browne-Cooper, R., and Robinson, D. (1995). 'A Guide to the Reptiles and Frogs of the Perth Region.' (University of Western Australia Press: Nedlands.)

Bush, B., Maryan B., Browne-Cooper, R., and Robinson, D. (2007). 'Reptiles and Frogs in the Bush: Southwestern Australia.' (University of Western Australia Press: Nedlands.) 
Cade, B. S. (2015). Model averaging and muddled multimodal inferences. Ecology 96, 23792382.

Christie, K., V. L. Stokes, V.L., Craig, M.D., and Hobbs, R.J. (2013). Microhabitat preference of Egernia napoleonis in undisturbed Jarrah forest, and availability and introduction of microhabitats to encourage colonization of restored forest. Restoration Ecology 21, 722-728.

Claridge, A., Hazell, D., Cunningham, R., Lindenmayer, D. B., Michael, D., Crane, M., and

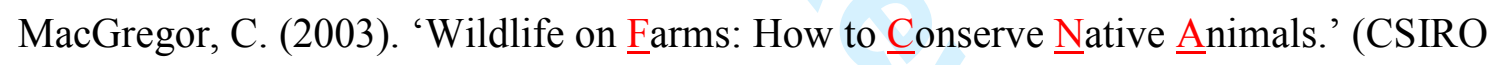
Publishing: Melbourne.)

Clarke, K.R., and Ainsworth, M. (1993). A method of linking multivariate community structure to environmental variables. Marine Ecology Progress Series 92, 205-219.

Craig, M. D., and Roberts, J. D. (2005). The short-term impacts of logging on the Jarrah forest avifauna in south-west western Australia: Implications for the design and analysis of logging experiments. Biological Conservation 124, 177-188.

Craig, M. D., Benkovic, A. M., Grigg, A. H, Hardy, G. E. S. J., Fleming, P. A., and Hobbs. R. J. (2011). How many mature microhabitats does a slow-recolonising reptile require? Implications for restoration of bauxite minesites in south-western Australia. Australian Journal of Zoology 59, 9-17. 
Craig, M. D., Garkaklis, M. J., Hardy, G. E. S. J., Grigg, A. H., Grant, C. D., Fleming, P. A., and Hobbs, R. J. (2007). Ecology of the western bearded dragon (Pogona minor) in unmined forest and forest restored after bauxite mining in south-west western Australia. Australian Journal of Zoology 55, 107-116.

Craig, M. D., Grigg, A. H., Garkaklis, M. J., Hobbs, R. J., Grant, C. D., Fleming, P. A., and Hardy, G. E. S. J. (2009). Does habitat structure influence capture probabilities? A study of reptiles in a eucalypt forest. Wildlife Research 36, 509-515.

Craig, M. D., Hardy, G. E. S. J., Fontaine, J. B., Garkakalis, M. J., Grigg, A. H., Grant, C. D.,

Fleming, P. A., and Hobbs R. J. (2012). Identifying unidirectional and dynamic habitat filters to faunal recolonisation in restored mine-pits. Journal of Applied Ecology 49, 919-928.

Craig, M. D., Hobbs, R. J., Grigg, A. H., Garkaklis, M. J., Grant, C. D., Fleming, P. A., and Hardy, G. E. S. J. (2010). Do thinning and burning sites revegetated after bauxite mining improve habitat for terrestrial vertebrates? Restoration Ecology 18, 300-310.

\section{Craig, M. D., Stokes, V. L., Hardy, G. E. S. J., and Hobbs, R. J. (2015). Edge effects across}

$\underline{\text { boundaries between natural and restored jarrah (Eucalyptus marginata) forests in south- }}$ western Australia. Austral Ecology 40, 186-197.

Cuccovia, A., and Kinnear, A. (1999). Acarine (mite) communities colonizing rehabilitated bauxite mine pits in the Jarrah forest of Western Australia. In 'The $\underline{\text { Other }} 99 \%$ : The Conservation and Biodiversity of Invertebrates'. (Eds. W. F. Ponder and D. Lunney.) pp. 5459. (Royal Zoological Society of New South Wales: Mosman.) 
Cunningham, R. B., Lindenmayer, D. B., Crane, M., Michael, D., and MacGregor, C. (2007). Reptile and arboreal marsupial response to replanted vegetation in agricultural landscapes. Ecological Applications 17, 609-619.

Dell, B., and Havel J. J. (1989). The Jarrah forest, an introduction. In 'The Jarrah Forest: A Complex Mediterranean Ecosystem’. (Eds. B. Dell, J. J. Havel, and N. Malajczuk.) pp. 1-10. (Kluwer Academic Publishers: Dordrecht.)

Doak, D. F., Gross, K., and Morris, W. F. (2005). Understanding and predicting the effects of sparse data on demographic analyses. Ecology 86, 1154-1163.

Driscoll, D. A. and Henderson, M. K. (2008). How many common reptile species are fire specialists? A replicated natural experiment highlights the predictive weakness of a fire succession model. Biological Conservation 141, 460-471.

Driscoll, D. A., Smith, A. L., Blight, S., and Maindonald, J. (2012). Reptile responses to fire and the risk of post-disturbance sampling bias. Biodiversity and Conservation 21, 1607-1625.

Eyre, T. J., Ferguson, D. J., Kennedy, M., Rowland, J., and Maron, M., 2015. Long term thinning and logging in Australian cypress pine forest: Changes in habitat attributes and response of fauna. Biological Conservation 186, 83-96.

Fergusson, B., and Algar, D. (1986). Home range and activity patterns of pregnant female skinks, Tiliqua rugosa. Wildlife Research 13, 287-294. 
Fischer, J., Lindenmayer, D. B., and Cowling, A. (2004). The challenge of managing multiple species at multiple scales: Reptiles in an Australian grazing landscape. Journal of Applied Ecology 41, 32-44.

Fisher, R. A., Corbet, A. S., and Williams, C. B. (1943). The relation between the number of species and the number of individuals in a random sample of an animal population. The Journal of Animal Ecology, 42-58.

Fiske, I., and Chandler, R. (2011). Unmarked: An r package for fitting hierarchical models on wildlife occurrence and abundance. Journal of Statistical Software 43, 1-23.

Fitzgerald, M., Shine, R., and Lemckert, F. (2002). Spatial ecology of arboreal snakes (Hoplocephalus stephensii, Elapidae) in an eastern Australian forest. Austral Ecology 27, $537-545$.

Garden, J. G., McAlpine, C. A., Possingham, H. P., and Jones, D. N. (2007). Habitat structure is more important than vegetation composition for local-level management of native terrestrial reptile and small mammal species living in urban remnants: A case study from Brisbane. Australia. Austral Ecology 32, 669-685.

Gardner, J., and Bell, D. (2007). Bauxite mining restoration by Alcoa World Alumina Australia in Western Australia: Social, political, historical, and environmental contexts. Restoration Ecology 15, S3-S10. 


\section{Goldingay, R., Daly, G. and Lemckert, F. (1996). Assessing the impacts of logging on}

reptiles and frogs in the montane forests of southern New South Wales. Wildlife Research $\mathbf{2 3}$, 495-510.

Gourret, A., Alford, R. A., and Schwarzkopf, L. (2011). Very small, light dipole harmonic tags for tracking small animals. Herpetological Review 42, 522-525.

Green, B., and King, D. (1978). Home range and activity patterns of the sand goanna, Varanus gouldii (reptilia: Varanidae). Wildlife Research 5, 417-424.

Groombridge, B. (1992). _Global Biodiversity: Status of the Earth's Living Resources.' (Chapman \& Hall: UK.)

Guisan, A., Broennimann, O., Engler, R., Vust, M., Yoccoz, N. G., Lehmann, A., and Zimmermann, N. E. (2006). Using niche-based models to improve the sampling of rare species. Conservation Biology 20, 501-511.

Heatwole, H., and Taylor, J. (1987). 'Ecology of Reptiles.' (Surrey Beatty and Sons Pty Limited: Chipping Norton.)

Hobbs, R. J., Yates, S. and Mooney, H. A. (2007). Long-term data reveal complex dynamics in grassland in relation to climate and disturbance. Ecological Monographs 77, 545-568. 
Kanowski, J. J., Reis, T. M., Catterall, C. P., and Piper, S. D. (2006). Factors affecting the use of reforested sites by reptiles in cleared rainforest landscapes in tropical and subtropical Australia. Restoration Ecology 14, 67-76.

$\underline{\text { Kavanagh, R. P., and Stanton, M. A. (2005). Vertebrate species assemblages and species }}$ sensitivity to logging in the forests of north-eastern New South Wales. Forest Ecology and Management 209, 309-341.

Kerr, G. D., and Bull, C. M. (2004). Microhabitat use by the scincid lizard Tiliqua rugosa: exploiting natural temperature gradients beneath plant canopies. Journal of Herpetology 38, $536-545$.

Kerr, G. D., and Bull, C. M. (2006). Exclusive core areas in overlapping ranges of the sleepy lizard, Tiliqua rugosa. Behavioral Ecology 17, 380-391.

Kerr, G. D., Bull, C. M., and Burzacott, D. (2003). Refuge sites used by the scincid lizard Tiliqua rugosa. Austral Ecology 28, 152-160.

Kéry, M., Royle, J. A., and Schmid, H. (2005). Modeling avian abundance from replicated counts using binomial mixture models. Ecological Applications 15, 1450-1461.

Kéry, M., Guillera-Arroita, G. and Lahoz-Monfort, J. J. (2013). Analysing and mapping species range dynamics using occupancy models. Journal of Biogeography 40, 1463-1474. 
Koellner, T., and Schmitz, O. J. (2006). Biodiversity, ecosystem function, and investment risk. BioScience 56, 977-985.

Kutt, A. S., Vanderduys, E. P., Ferguson, D., and Mathieson, M. (2012). Effect of small-scale woodland clearing and thinning on vertebrate fauna in a largely intact tropical savanna mosaic. Wildlife Research 39, 366-373.

Lindenmayer, D., Wood, J., Montague-Drake, R., Michael, D., Crane, M., Okada, S., MacGregor, C., and Gibbons, P. (2012). Is biodiversity management effective? Crosssectional relationships between management, bird response and vegetation attributes in an Australian agri-environment scheme. Biological Conservation 152, 62-73.

MacKenzie, D. I., Nichols, J. D., Hines, J. E., Knutson, M. G., and Franklin, A. B. (2003).

Estimating site occupancy, colonization, and local extinction when a species is detected imperfectly. Ecology 84, 2200-2207.

MacKenzie, D. I., Nichols, J. D., Royle, J. A., Pollock, K. H., Hines, J. E., and Bailey, L. L. (2006). 'Occupancy Estimation and Modeling: Inferring Patterns and Dynamics of Species Occurrence.'. (Elsevier: USA.)

MacNally, R., and Brown G. W. (2001). Reptiles and habitat fragmentation in the boxironbark forests of central Victoria, Australia: Predictions, compositional change and faunal nestedness. Oecologia 128, 116-125. 
Magurran, A. E., and Henderson, P. A. (2003). Explaining the excess of rare species in natural species abundance distributions. Nature 422, 714 .

Main, A. R. (1982). Rare species: Precious or dross? In ‘Species at Risk: Research in Australia'. (Eds. R. H. Groves and W. D. L. Ride.) pp. 163 - 174. (Australian Academy of Science: Canberra.)

Majer, J. D., Brennan, K. E. C., and Moir, M. L. (2007). Invertebrates and the restoration of a forest ecosystem: 30 years of research following bauxite mining in Western Australia. Restoration Ecology 15, S104-S115.

Morrison, M. L., Marcot, B. G., and Mannan, R. W. (2006). 'Wildlife- $\underline{\text { Habitat }}$ Relationships: Concepts and Applications.' (Island Press :USA.)-

Morrison, M. L, Block, W. M., Strickland, D. R., Collier, B. A., and Peterson, M. J. (2008).

'Wildlife study design.' 2nd edn. (Springer-Verlag: USA.))

Morrison, M. L. (2009). 'Restoring Wildlife: Ecological Concepts and Practical Applications.' (Island Press: USA.)

Myers, N., Mittermeier, R. A., Mittermeier, C. G., da Fonseca, G.A.B., and Kent, J. (2000). Biodiversity hotspots for conservation priorities. Nature 403, 853-858. 
Nichols, O. G., and Bamford, M. J. (1985). Reptile and frog utilisation of rehabilitated bauxite minesites and dieback-affected sites in Western Australia's Jarrah Euclayptus marginata forest. Biological Conservation 34, 227-249.

Nichols, O. G., and Grant, C. D. (2007). Vertebrate fauna recolonization of restored bauxite mines-key findings from almost 30 years of monitoring research. Restoration Ecology 15, S116-S126.

Nichols, O. G., and B. Muir. 1989. Vertebrates of the Jarrah forest. In 'The Jarrah Forest: A Complex Mediterranean Ecosystem'. (Eds. B. Dell, J. J. Havel, and N. Malajczuk.) pp. 133153. (Kluwer Academic Publishers: Dordrecht.)

Nichols, O. G., and F. M. Nichols. (2003). Long-term trends in faunal recolonization after bauxite mining in the Jarrah forest of southwestern Australia. Restoration Ecology 11, 261272.

Oksanen, J., Blanchet, F. G., Roeland, K., Legendre, P., Minchin, P. R., O'Hara, R. B., Simpson, G. L., Solymos, P., Stevens, M. H. H., and Wagner, H. (2015). Vegan: Community ecology package. R package version 2.0-1.

Pekin, B., and Macfarlane, C. (2009). Measurement of crown cover and leaf area index using digital cover photography and its application to remote sensing. Remote Sensing 1, 12981320. 
Penn, A. M., Sherwin, W. B., Lunney, D. and Banks, P. B. (2003). The effects of a lowintensity fire on small mammals and lizards in a logged, burnt forest. Wildlife Research 30, $\underline{477-486 .}$

Pianka, E. R. (1986). 'Ecology and Natural History of Desert Lizards.' (Princeton University Press: Princeton.)

Pianka, E. R. (1989). Desert lizard diversity: additional comments and some data. American Naturalist 134, 344-364.

Pianka, E. R. (2011a). Notes on the natural history of the tiny skink Menetia greyi. Western Australian Naturalist 28, 12-17.

Pianka, E. R. (2011b). Notes on the ecology of some uncommon skinks in the Great Victoria Desert. Western Australian Naturalist 28, 50-60.

Pianka, E. R., and Goodyear, S.E. (2012). Lizard responses to wildfire in arid interior Australia: Long-term experimental data and commonalities with other studies. Austral Ecology 37, 1-11.

Pianka, E. R., and Harp, C.A. (2011). Snake-eyed skink Cryptoblepharus buchananii in arid Western Australia. Western Australian Naturalist 28, 43-49.

Pimm, S. L., and Raven, P. (2000). Biodiversity: Extinction by numbers. Nature 403, 843845. 
R Core Team. (2016). R: A language and environment for statistical computing. R Foundation for Statistical Computing, Vienna, Austria.

Ryan, T. J., Philippi, T., Leiden, Y. A., Dorcas, M. E., Wigley, T. B., and Gibbons, J. W. (2002). Monitoring herpetofauna in a managed forest landscape: Effects of habitat types and census techniques. Forest Ecology and Management 167, 83-90.

Sala, O. E., Chapin, F. S. I., Armesto, J. J., Berlow, E., Bloomfield, J., Dirzo, R., HuberSanwald, E., Huenneke, L. F., Jackson, R. B., Kinzig, A., Leemans, R., Lodge, D. M., Mooney, H. A., Oesterheld, M., Poff, N. L., Sykes, M. T., Walker, B. H., Walker, M., and Wall, D. H. (2000). Global biodiversity scenarios for the year 2100. Science 287, 1770.

Schmidt, W., and Mason, M. (1973). The effect of prescribed burning on the fauna of the Jarrah forest. Forest Department, Perth, Western Australia, Research Paper 11.

Schoener, T. W. (1974). Resource partitioning in ecological communities. Science 185, 2739.

Simmonds, S. J., Majer, J. D., and Nichols, O. G. (1994). A comparative study of spider (Araneae) communities of rehabilitated bauxite mines and surrounding forest in the southwest of Western Australia. Restoration Ecology 2, 247-260.

Smith, G. T., Arnold, G. W., Sarre, S., Abensperg-Traun, M., and Steven, D. E. (1996). The effect of habitat fragmentation and livestock grazing on animal communities in remnants of http://www.publish.csiro.au/journals/ajz 
gimlet Eucalyptus salubris woodland in the Western Australian wheatbelt. II. Lizards.

Journal of Applied Ecology 33, 1302-1310.

Spence-Bailey, L. M., Nimmo, D. G., Kelly, L. T., Bennett, A. F., and Clarke, M. F. (2010).

Maximising trapping efficiency in reptile surveys: The role of seasonality, weather conditions and moon phase on capture success. Wildlife Research 37, 104-115.

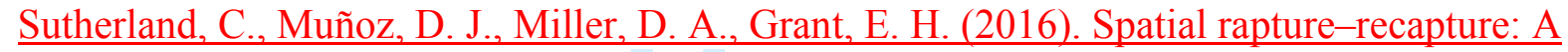
promising method for analyzing data collected using artificial cover objects. Herpetologica $\underline{72,6-12 .}$

Taylor, J. E. and Fox, B. J. (2001). Disturbance effects from fire and mining produce different lizard communities in eastern Australian forests. Austral Ecology 26, 193-204.

Thompson, S. K., and Seber, G. A. F. (1996). 'Adaptive S sampling.' (John Wiley and Sons: New York.)

Thompson, G. G., Withers, P. C., Pianka, E.R., and Thompson, S. A. (2003). Assessing biodiversity with species accumulation curves; inventories of small reptiles by pit-trapping in Western Australia. Austral Ecology, 28, 361-383.

Valentine, L. E., Reaveley, A., Johnson, B., Fisher, R., and Wilson, B. A. (2012). Burning in Banksia Woodlands: How does the fire-free period influence reptile communities? PloS ONE $\underline{7, \mathrm{e} 34448 .}$ 
Wayne, A., I. Wheeler, C. Ward, J. Rooney, and A. Mellican. (2001). The impacts of timber harvesting and associated activities on the small terrestrial vertebrates of the Jarrah forest:

$\underline{\text { Kingston progress report. Department of Conservation and Land Management, Perth, }}$ $\underline{\text { Australia. }}$

Welbourne, D. J., MacGregor, C., Paull, D., and Lindenmayer, D. B. (2015). The effectiveness and cost of camera traps for surveying small reptiles and critical weight range mammals: A comparison with labour-intensive complementary methods. Wildlife Research 42, 414-425.

Welsh, A. H., Lindenmayer, D. B., and Donnelly, C. F. (2013). Fitting and interpreting occupancy models. PLOS ONE 8, e52015.

Whitford, K. R., Faunt, K., and Swinburn, M. L. (2008). The impact of timber harvesting on the size, amount, and decay status of large coarse woody debris in the Jarrah (Eucalyptus marginata) forest. pp. 73 In 'Old Forest, New Management Conference Proceedings.'-, (Hobart, 17-21 February 2008.)

Williams, K., and Mitchell, D. (2001). 'Jarrah forest 1 (JF1 - northern Jarrah forest subregion).' In 'A Biodiversity Audit of Western Australia's 53 Biogeographic Subregions in 2002'. (Eds. N._L. McKenzie, J._E. May, and S. McKenna.) pp. 369-381. (Department of Conservation and Land Management: Kensington.) 
Yachi, S., and Loreau, M. (1999). Biodiversity and ecosystem productivity in a fluctuating environment: The insurance hypothesis. Proceedings of the National Academy of Sciences 96, $1463-1468$.

Yeatman, G. J., Wayne, A. F., Mills, H. R. and Prince, J. (2017). It's not all about the creeks: protection of multiple habitats will improve biodiversity conservation in a eucalypt forest. Australian Journal of Zoology 64, 292-301. 
Table 1. Reptile species detected

The total number of detections (No. detections) summed over all sites and all years and the number of sites occupied by each species (No. sites occupied; $n=35$ ). Five skink species make up $\geq 80 \%$ of the total number of detections. Species were grouped into common $(C)$, uncommon $(\mathrm{U})$ and rare $(\mathrm{R})$ categories for analysis; with rare species containing too few detections for any individual analysis.

\begin{tabular}{lccc}
\hline & & & \\
Species & No. Detections (\%) & No. sites occupied (\%) & Group \\
\hline Morethia obscura (Scincidae) & $171(24.22)$ & $33(94.29)$ & $\mathrm{C}$ \\
Menetia greyii (Scincidae) & $113(16.01)$ & $25(71.42)$ & $\mathrm{C}$ \\
Hemiergis initialis (Scincidae) & $107(15.16)$ & $31(88.57)$ & $\mathrm{C}$ \\
Lerista distinguenda (Scincidae) & $105(14.87)$ & $22(57.14)$ & $\mathrm{C}$ \\
Acritoscincus trilineatus (Scincidae) & $77(10.91)$ & $28(80.00)$ & $\mathrm{C}$ \\
Egernia napoleonis (Scincidae) & $38(5.38)$ & $23(65.71)$ & $\mathrm{U}$ \\
Ctenotus labillardieri (Scincidae) & $25(3.54)$ & $14(40.00)$ & $\mathrm{U}$ \\
Cryptoblepharus buchananii (Scincidae) & $17(2.41)$ & $10(28.57)$ & $\mathrm{U}$ \\
Diplodactylus lateroides (Gekkonidae) & $15(2.12)$ & $10(28.57)$ & $\mathrm{U}$ \\
Christinus marmoratus (Gekkonidae) & $13(1.84)$ & $8(22.86)$ & $\mathrm{U}$ \\
Aprasia pulchella (Pygopodidae) & $9(1.27)$ & $6(17.14)$ & $\mathrm{R}$ \\
Ramphotyphlops australis (Typhlopidae) & $4(0.57)$ & $2(5.71)$ & $\mathrm{R}$ \\
Tiliqua rugosa (Scincidae) & $4(0.28)$ & $2(5.71)$ & $\mathrm{R}$ \\
Varanus rosenbergi (Varanidae) & $3(0.42)$ & $3(8.57)$ & $\mathrm{R}$ \\
Parasuta nigriceps (Elapidae) & $2(0.28)$ & $2(5.71)$ & $\mathrm{R}$ \\
Pogona minor (Agamidae) & $2(0.28)$ & $2(5.71)$ & $\mathrm{R}$ \\
Lerista microtis (Scincidae) & $1(0.14)$ & $1(2.86)$ & $\mathrm{R}$ \\
Total & 706 & & \\
\hline
\end{tabular}


Table 2. Occupancy model output for common reptile species

Summary of well-supported ( $\triangle \mathrm{AIC}<2$ from top model) occupancy models for the 5 most common species. The table includes $\underline{\Delta A I C}$ values, Akaike weights $(\omega)$, the number of parameters $(\mathrm{nP})$, the trend of detection probability (p) and occupancy $(\Psi)$ indicating changes associated habitat or seasonal variables $(\cap=$ optimal value; $\uparrow=$ increasing; $\downarrow=$ decreasing; $\leftrightarrow=$ no influence). Models with weights $\geq 0.5$ are bold. Additionally, it includes goodness of fit (GoF) results for each species from the top model with a non-significant p-value indicating model fit.

\begin{tabular}{|c|c|c|c|c|c|c|c|}
\hline Species & Model $^{\mathrm{a}}$ & $\Delta \mathbf{A I C}$ & $\omega$ & $\underline{\mathrm{nP}}$ & $\begin{array}{c}p \\
\text { trend }\end{array}$ & $\begin{array}{c}\Psi \\
\text { trend }\end{array}$ & GoF (p) \\
\hline \multirow[t]{2}{*}{ M. obscura } & $\mathrm{p}\left(\mathrm{MaxT}^{2}\right), \Psi(\mathrm{OD})$ & $\underline{0.00}$ & $0 . \underline{46}$ & $\underline{7}$ & $\cap$ & $\downarrow$ & 0.28 \\
\hline & $\mathrm{p}\left(\mathrm{MaxT}^{2}\right), \Psi()$. & $\underline{2.25}$ & $0.1 \underline{5}$ & $\underline{6}$ & $\cap$ & $\leftrightarrow$ & \\
\hline \multirow[t]{2}{*}{ L. distinguenda } & $\mathrm{p}\left(\mathrm{MaxT}^{2}\right), \Psi(0-1 \mathrm{~m})$ & $\underline{0.00}$ & $\underline{0.47}$ & 7 & $\cap$ & $\downarrow$ & 0.42 \\
\hline & $\mathrm{p}\left(\mathrm{MaxT}^{2}\right), \Psi(\mathrm{OD})$ & $\underline{1.59}$ & $0.2 \underline{2}$ & $\underline{7}$ & $\cap$ & $\downarrow$ & \\
\hline \multirow[t]{4}{*}{ H. initialis } & $\mathrm{p}$ (Month), $\Psi(1-2 \mathrm{~m})$ & $\underline{0.00}$ & $0.2 \underline{3}$ & $\underline{8}$ & $\uparrow \downarrow$ & $\uparrow$ & 0.53 \\
\hline & $\mathrm{p}$ (Month), $\Psi(\mathrm{OD})$ & $\underline{0.81}$ & 0.16 & $\underline{8}$ & $\uparrow \downarrow$ & $\uparrow$ & \\
\hline & p(Month), $\Psi(C W D)$ & $\underline{0.86}$ & $0.1 \underline{5}$ & $\underline{8}$ & $\uparrow \downarrow$ & $\downarrow$ & \\
\hline & $\mathrm{p}$ (Month), $\Psi(0-1 \mathrm{~m})$ & $\underline{1.46}$ & 0.11 & $\underline{8}$ & $\uparrow \downarrow$ & $\uparrow$ & \\
\hline \multirow[t]{2}{*}{ M. greyii } & $\mathrm{p}(\operatorname{MaxT}), \Psi(1-2 \mathrm{~m})$ & $\underline{0.00}$ & $\underline{0.37}$ & $\underline{6}$ & $\uparrow$ & $\downarrow$ & 0.19 \\
\hline & $\mathrm{p}(\operatorname{MaxT}), \Psi()$. & $\underline{1.96}$ & $\underline{0.15}$ & $\underline{6}$ & $\uparrow$ & $\downarrow$ & \\
\hline \multirow[t]{2}{*}{ A. trilineatus } & p(MaxT), $\Psi(2-5 m)$ & $\underline{0.00}$ & $0 . \underline{67}$ & $\underline{6}$ & $\uparrow$ & $\uparrow$ & 0.55 \\
\hline & $\mathrm{p}(\operatorname{MaxT}), \Psi(0-1 \mathrm{~m})$ & & 0.07 & & $\hat{\uparrow}$ & $\hat{\uparrow}$ & \\
\hline
\end{tabular}

${ }^{\mathrm{a}}$ Model descriptors: $\operatorname{MaxT}^{2}=$ maximum temperature squared, MaxT $=$ maximum temperature, $\mathrm{OD}=$ overstorey density, $0-1 \mathrm{~m}=0-1 \mathrm{~m}$ cover, $\mathrm{CWD}=$ coarse woody debris, Month=month surveyed, $\mathrm{LL}=$ leaf litter, $2-5 \mathrm{~m}=2-5 \mathrm{~m}$ cover, and $1-2 \mathrm{~m}=1-2 \mathrm{~m}$ cover, and (.) indicates a null model. 
Table 3. Poisson regression output for uncommon reptile species

\begin{tabular}{|c|c|c|c|c|c|c|c|c|c|}
\hline & $0-1 \mathrm{~m}$ & $1-2 m$ & $2-5 m$ & OD & $\mathrm{CC}$ & LL & CWD & FuelAge & PropRest \\
\hline \multicolumn{10}{|l|}{ E. napoleonis } \\
\hline estimate & 0.015 & -0.002 & 0.019 & 0.000 & 0.001 & 0.016 & 0.000 & -0.020 & -0.015 \\
\hline SE & 0.015 & 0.007 & 0.018 & 0.000 & 0.006 & 0.027 & 0.000 & 0.022 & 0.025 \\
\hline z-value & 1.032 & 0.280 & 0.998 & 0.256 & 0.221 & 0.574 & 0.068 & 0.888 & 0.566 \\
\hline $\mathrm{p}$-value & 0.302 & 0.779 & 0.318 & 0.798 & 0.825 & 0.566 & 0.946 & 0.374 & 0.572 \\
\hline relative importance & 1.000 & 0.271 & 0.967 & 0.248 & 0.214 & 0.556 & 0.066 & 0.860 & 0.548 \\
\hline \multicolumn{10}{|l|}{ C. labillardieri } \\
\hline estimate & -0.001 & 0.000 & 0.008 & 0.000 & 0.013 & 0.023 & 0.000 & -0.076 & -0.017 \\
\hline SE & 0.007 & 0.006 & 0.016 & 0.000 & 0.020 & 0.039 & 0.001 & 0.030 & 0.038 \\
\hline $\mathrm{z}$-value & 0.212 & 0.003 & 0.500 & 0.112 & 0.628 & 0.582 & 0.326 & 2.488 & 0.422 \\
\hline $\mathrm{p}$-value & 0.832 & 0.998 & 0.617 & 0.911 & 0.530 & 0.561 & 0.744 & 0.013 & 0.673 \\
\hline relative importance & 0.085 & 0.001 & 0.201 & 0.045 & 0.252 & 0.234 & 0.131 & 1.000 & 0.170 \\
\hline \multicolumn{10}{|l|}{ D. lateroides } \\
\hline estimate & -0.002 & 0.008 & -0.011 & 0.000 & 0.005 & -0.004 & 0.003 & 0.016 & 0.000 \\
\hline SE & 0.010 & 0.016 & 0.024 & 0.000 & 0.014 & 0.025 & 0.002 & 0.031 & 0.014 \\
\hline z-value & 0.173 & 0.464 & 0.428 & 0.374 & 0.321 & 0.161 & 1.656 & 0.510 & 0.033 \\
\hline $\mathrm{p}$-value & 0.863 & 0.643 & 0.669 & 0.709 & 0.748 & 0.873 & 0.098 & 0.610 & 0.974 \\
\hline relative Importance & 0.104 & 0.280 & 0.258 & 0.226 & 0.194 & 0.097 & 1.000 & 0.308 & 0.020 \\
\hline \multicolumn{10}{|l|}{ C. marmoratus } \\
\hline estimate & -0.084 & 0.026 & -0.025 & 0.000 & -0.002 & 0.002 & 0.000 & 0.000 & 0.000 \\
\hline SE & 0.029 & 0.037 & 0.042 & 0.000 & 0.009 & 0.022 & 0.001 & 0.013 & 0.010 \\
\hline z-value & 2.860 & 0.681 & 0.597 & 0.082 & 0.192 & 0.075 & 0.142 & 0.025 & 0.046 \\
\hline $\mathrm{p}$-value & 0.004 & 0.496 & 0.551 & 0.935 & 0.848 & 0.940 & 0.887 & 0.980 & 0.963 \\
\hline relative importance & 1.000 & 0.238 & 0.209 & 0.029 & 0.067 & 0.026 & 0.050 & 0.009 & 0.016 \\
\hline \multicolumn{10}{|l|}{ C. buchananii } \\
\hline estimate & -0.045 & 0.021 & -0.010 & 0.000 & 0.013 & 0.000 & 0.000 & 0.099 & 0.000 \\
\hline SE & 0.031 & 0.032 & 0.023 & 0.000 & 0.020 & 0.018 & 0.001 & 0.046 & 0.007 \\
\hline z-value & 1.421 & 0.632 & 0.435 & 0.370 & 0.635 & 0.004 & 0.123 & 2.057 & 0.000 \\
\hline $\mathrm{p}$-value & 0.155 & 0.528 & 0.664 & 0.711 & 0.526 & 0.997 & 0.902 & 0.040 & 1.000 \\
\hline relative importance & 0.691 & 0.307 & 0.211 & 0.180 & 0.309 & 0.002 & 0.060 & 1.000 & 0.000 \\
\hline
\end{tabular}

Poisson regression top models and model-average estimates. The table includes habitat covariates and their influence: decreasing (-), or increasing $(+)$, standard errors (SE), z-

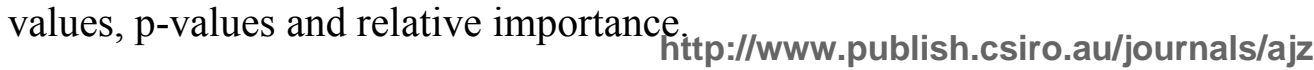


4 a Model descriptors $0-1 \mathrm{~m}=0-1 \mathrm{~m}$ cover, $1-2 \mathrm{~m}=1-2 \mathrm{~m}$ cover, , $2-5 \mathrm{~m}=2-5 \mathrm{~m}$ cover, $\mathrm{OD}=$ overstorey density, $\mathrm{CC}=$ canopy cover $\mathrm{LL}=$ leaflitter, $\mathrm{CWD}=$ coarse woody debris, FuelAge=time since the last fire, and PropRest=the proportion of restored area within $100 \mathrm{~m}$. 


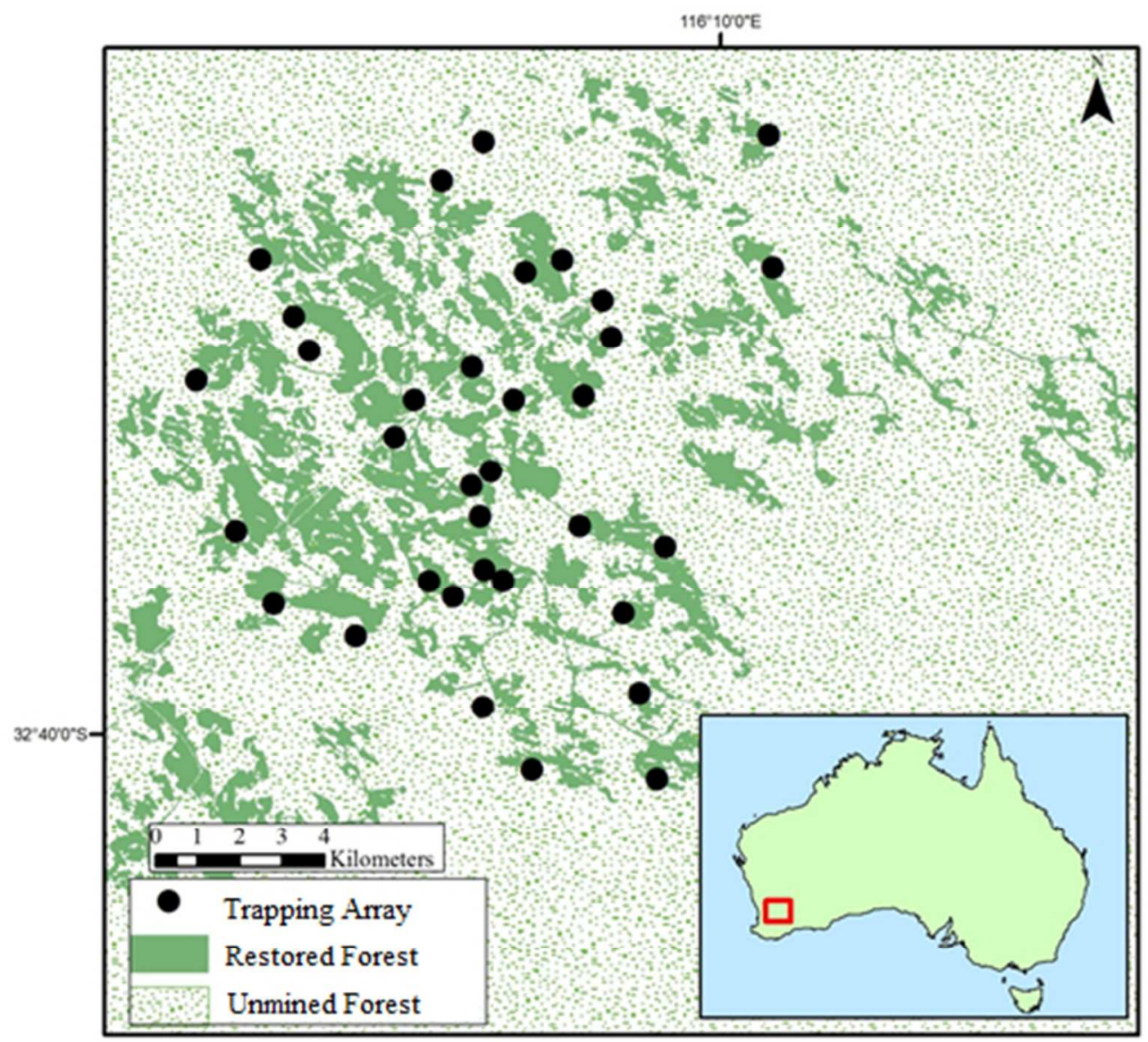

Map of Huntly minesite showing the mosaic of unmined and restored forest across the landscape. All trapping arrays were located in unmined forest.

Fig. 1 


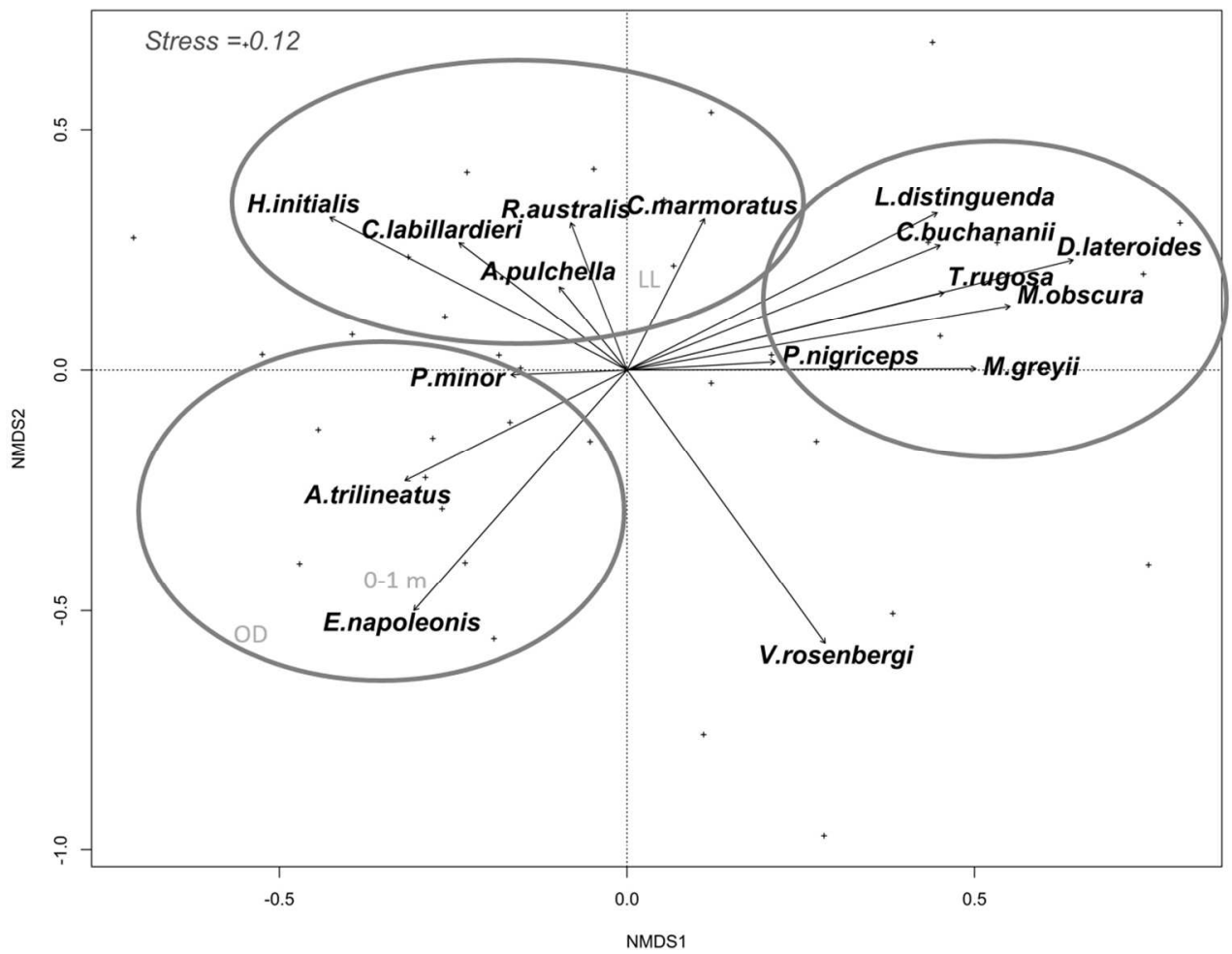

Procrustes analysis of reptile abundance data obtained at 35 sites in the Jarrah forest, with lines indicating species (black arrows) and grey text indicating the location of habitat covariate correlations at sites (+) with the arrows and text location indicating the direction of the relationship and the length of the line indicating the strength of the correlation between the ordination and the variable. Only significant habitat variables are shown (OD = overstorey density; $0-1 \mathrm{~m}=$ percent cover from 0 to $1 \mathrm{~m}$; $\mathrm{LL}=$ percent leaf litter). 
1 Table S1. Variations in yearly sampling

2 Sites were surveyed for reptiles between 2005 and 2013, but not in all years as displayed

3 below. The number of trapping arrays includes the number of reference forest sites that were

4 surveyed.

\begin{tabular}{|c|c|c|c|c|c|c|c|c|c|}
\hline Year & Month & & & & & & & & \\
\hline \multirow{2}{*}{2005} & Oct & $\mathrm{x}$ & $\mathrm{x}$ & & & & & & \\
\hline & Dec & $\mathrm{x}$ & $\mathrm{x}$ & & & & & & \\
\hline \multirow{4}{*}{2006} & Mar & $\mathrm{x}$ & $\mathrm{x}$ & & & & & & \\
\hline & May & $\mathrm{x}$ & $\mathrm{x}$ & & & & & & \\
\hline & Oct & & & $\mathrm{x}$ & & & & & \\
\hline & Dec & & & $\mathrm{x}$ & & & & & \\
\hline \multirow{2}{*}{2007} & Mar & & & $\mathrm{x}$ & & & & & \\
\hline & May & & & $\mathrm{x}$ & & & & & \\
\hline \multirow{3}{*}{2009} & Oct & & & & $\mathrm{x}$ & & & & \\
\hline & Nov & & & & $\mathrm{x}$ & & & & \\
\hline & Dec & & & & $\mathrm{x}$ & & & & \\
\hline \multirow{4}{*}{2010} & Mar & & & & $\mathrm{x}$ & & & & \\
\hline & Oct & & & & & $\mathrm{x}$ & & & \\
\hline & Nov & & & & & $\mathrm{x}$ & & & \\
\hline & Dec & & & & & $\mathrm{x}$ & & & \\
\hline \multirow{4}{*}{2011} & Mar & & & & & $\mathrm{x}$ & & & \\
\hline & Oct & & & & & & $\mathrm{x}$ & $\mathrm{x}$ & \\
\hline & Nov & & & & & & $\mathrm{x}$ & $\mathrm{x}$ & \\
\hline & Dec & & & & & & $\mathrm{x}$ & $\mathrm{x}$ & \\
\hline \multirow[t]{4}{*}{2012} & Mar & & & & & & $\mathrm{x}$ & $\mathrm{x}$ & \\
\hline & Oct & & & & & & & & $\mathrm{x}$ \\
\hline & Nov & & & & & & & & $\mathrm{x}$ \\
\hline & Dec & & & & & & & & $\mathrm{x}$ \\
\hline \multirow[t]{2}{*}{2013} & Mar & & & & & & & & $\mathrm{x}$ \\
\hline & No. arrays & 4 & 4 & 4 & 4 & 2 & 10 & 2 & 5 \\
\hline
\end{tabular}

5

6

7 
8 Table S2. Summary of habitat variables

9 Descriptive statistics of the habitat variables measured at all reference forest sites (minus

10 correlated variables). Habitat variables are: percent cover in the three strata $0-1,1-2$ and 2-

$115 \mathrm{~m}$; percent cover of leaf litter (LL); percent canopy cover (CC); overstorey density (OD;

12 stems ha $\left.{ }^{-1}\right)$; log volume of coarse woody debris (CWD; $\left.\mathrm{m}^{3} \mathrm{ha}^{-1}\right)$; maximum temperature

13 (MaxT; $\left.{ }^{\circ} \mathrm{C}\right)$; minimum temperature $\left(\operatorname{MinT} ;{ }^{\circ} \mathrm{C}\right)$; precipitation in the last 2 weeks (Precip2;

$14 \mathrm{~mm}$ ); and the number of days since rainfall (RainD).

15

\begin{tabular}{lccccccc}
\hline & $0-1 \mathrm{~m}$ & $1-2 \mathrm{~m}$ & $2-5 \mathrm{~m}$ & LL & CC & OD & CWD \\
\hline Max & 67.70 & 65.08 & 44.03 & 100.00 & 62.75 & 18647.83 & 520.93 \\
Min & 4.42 & 0.30 & 0.00 & 68.33 & 0.00 & 416.72 & 0.67 \\
Mean & $\mathbf{4 3 . 6 1}$ & $\mathbf{1 5 . 2 3}$ & $\mathbf{1 2 . 7 9}$ & $\mathbf{9 2 . 7 6}$ & $\mathbf{4 1 . 8 1}$ & $\mathbf{3 2 2 1 . 1 7}$ & $\mathbf{1 4 4 . 2 7}$ \\
SE & 2.68 & 2.34 & 1.85 & 1.23 & 2.89 & 608.66 & 25.24 \\
\hline
\end{tabular}

16

\begin{tabular}{lcccc}
\hline & MaxT & MinT & Precip2 & RainD \\
\hline Max & 36.30 & 25.34 & 106.55 & 51.50 \\
Min & 15.50 & 3.50 & 0.00 & 0.00 \\
Mean & $\mathbf{2 4 . 8 5}$ & $\mathbf{1 1 . 6 7}$ & $\mathbf{3 5 . 3 9}$ & $\mathbf{8 . 9 5}$ \\
SE & 0.20 & 0.54 & 6.02 & 1.78 \\
\hline
\end{tabular}

17

18 


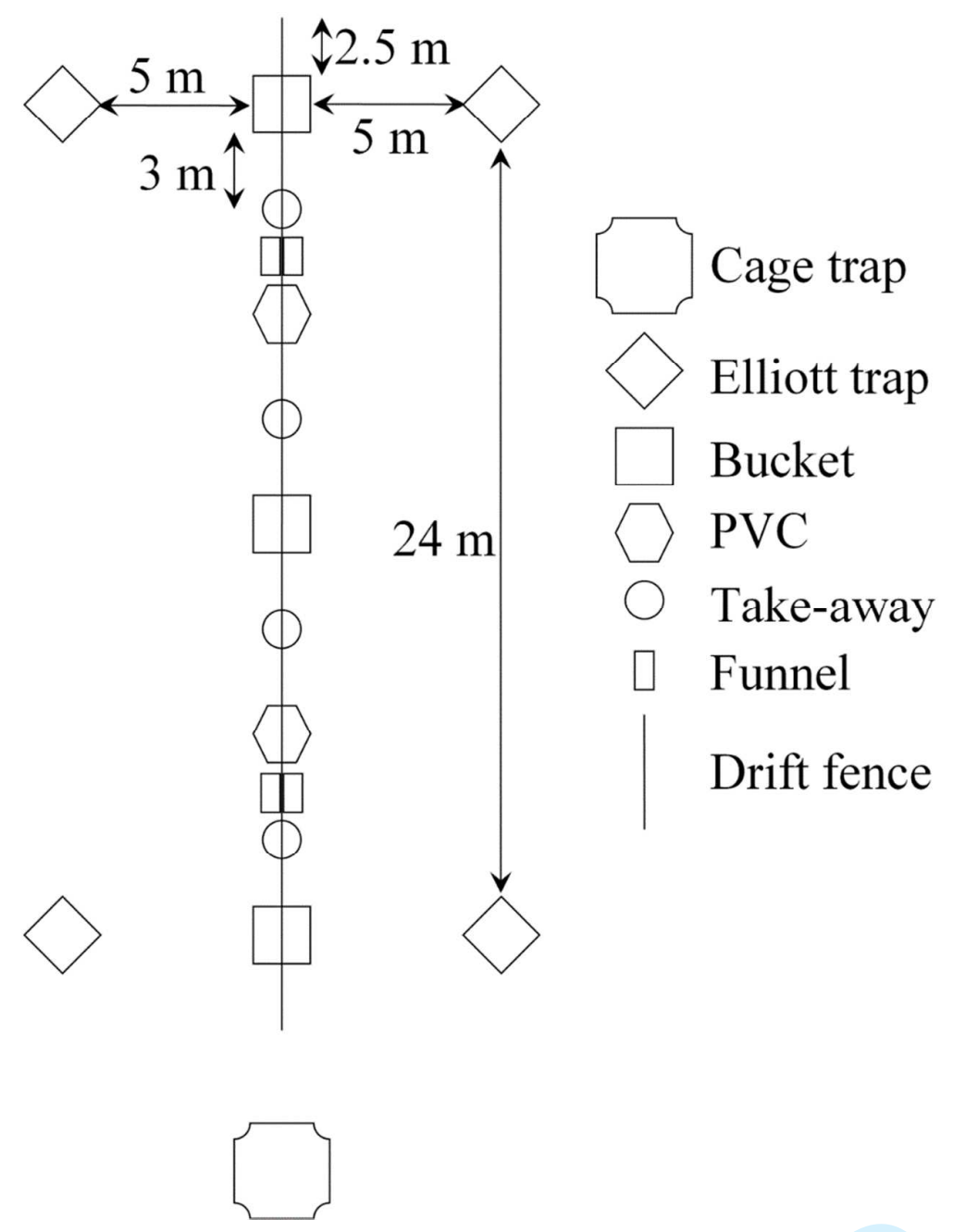

\section{Fig. S1.}

21 The layout of trapping arrays and vegetation surveys used to detect reptiles in the Jarrah

22 forest. The pitfall traps included three $20 \mathrm{~L}$ plastic buckets (Bucket), four $850 \mathrm{~mL}$ plastic,

23 take-away containers (Take-away), and two $40 \mathrm{~cm}$ long by $15 \mathrm{~cm}$ diameter PVC tubing

24 located every $3 \mathrm{~m}$ along a $29 \mathrm{~m}$ aluminium fly-wire drift fence, and two paired funnel traps

25 located on both sides of the drift fence between take-aways and PVC tubes. Four Elliot traps

26 were located $5 \mathrm{~m}$ on both sides of the end buckets and one cage trap was placed in line with

27 the drift fence $\sim 5 \mathrm{~m}$ from one of the end buckets. 


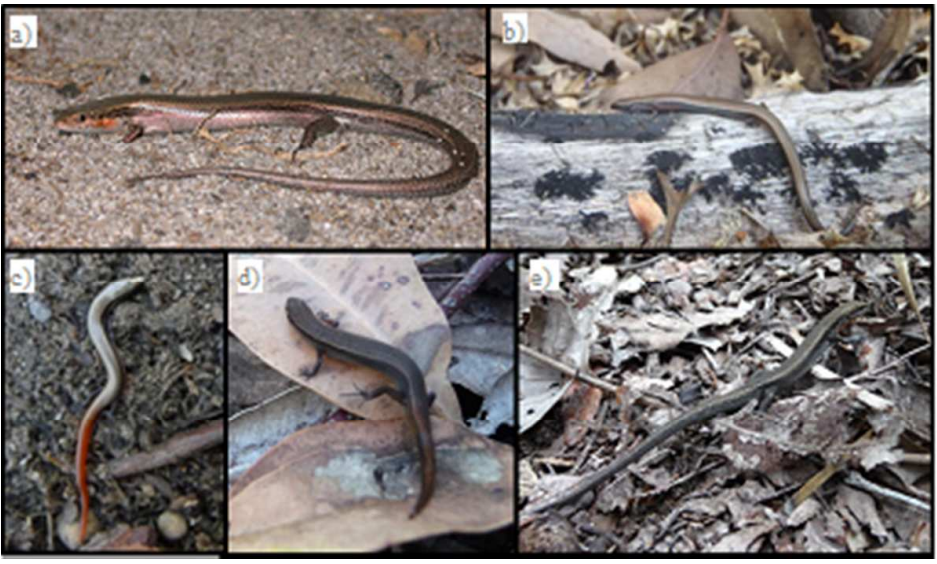

$31 \quad$ Fig. S2.

32 The five most commonly detected reptiles in the Jarrah forest during surveys from 2005-

33 2012; a) Acritoscincus trilineatus, b) Hemiergis initialis, c) Lerista distinguenda, d) Menetia

34 greyii and e) Morethia obscura.

35

36

37

38

39

40

41

42

43

44

45

46

47

48

49

http://www.publish.csiro.au/journals/ajz 


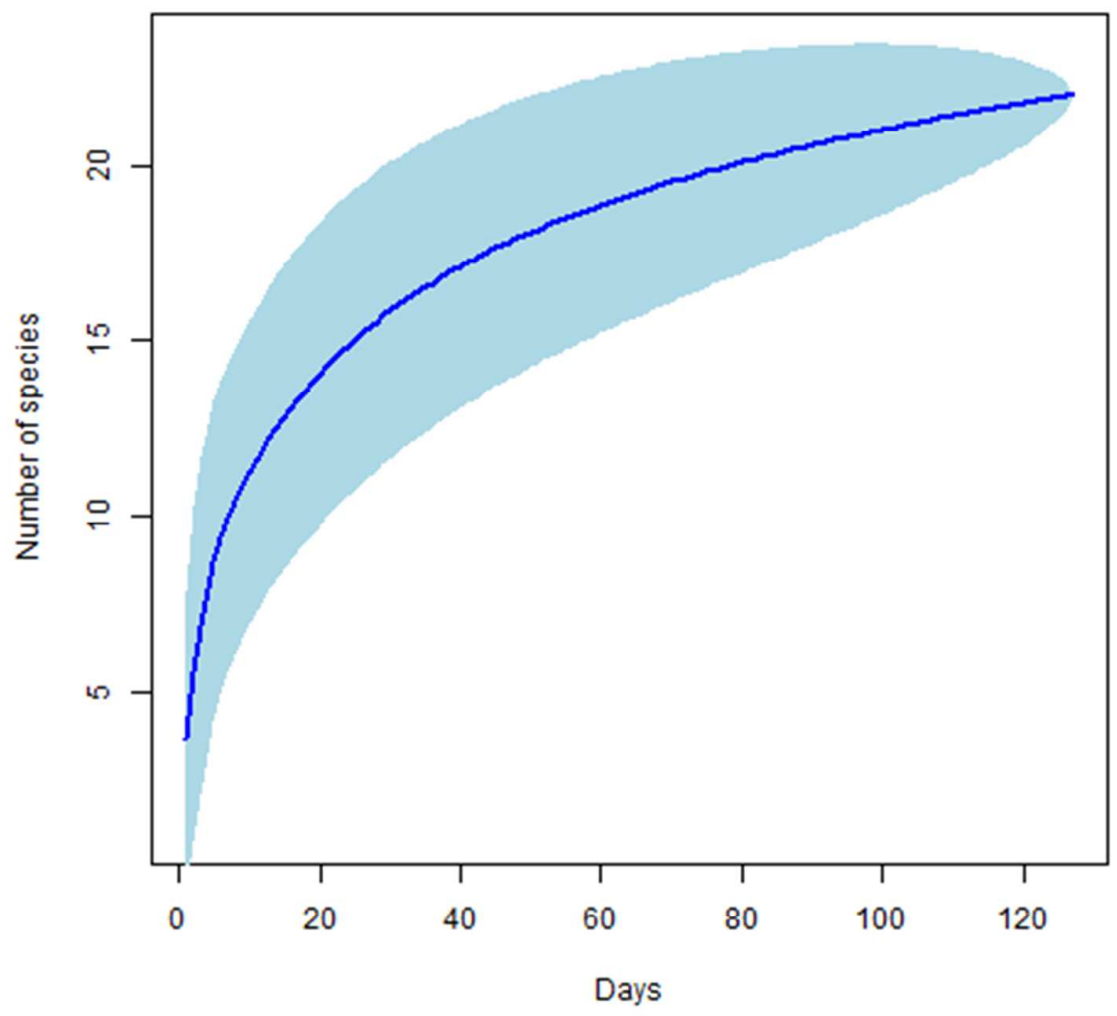

50

\section{$51 \quad$ Fig. S3.}

52 Species accumulation curve of the number of species detected by the number of days

53 surveyed; with each day weighted by the number of sites that were open that day. The

54 number of species detected increased rapidly until $\sim 80$ days after which time few new species

55 were detected.

56 

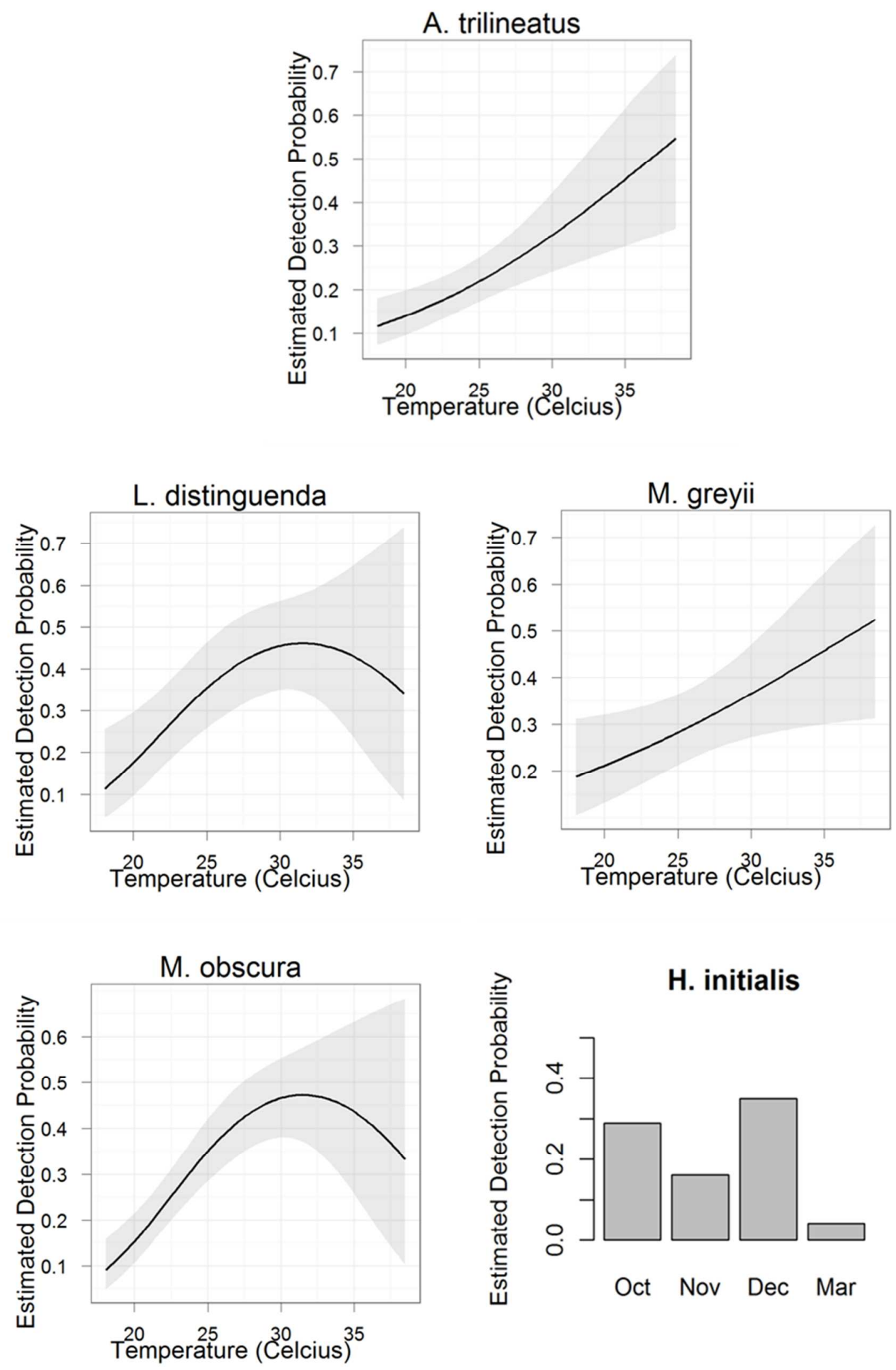

58 Fig. S4. Examples of detection probability for the best fit models for common reptile species 59 detected in the Jarrah forest. 